\title{
EFL Teacher's Instructional Design in Conducting Online Learning during the Covid-19 Pandemic
}

\author{
Liza Amelia Syafitri ${ }^{1}$, Yousef Bani Ahmad ${ }^{2}$, Abdul Kodir Al-Baekani ${ }^{3 *}$ \\ ${ }^{1}$ (English Education Deparment, Singaperbangsa University of Karawang, Indonesia) \\ ${ }^{3}$ (English Education Deparment, Singaperbangsa University of Karawang, Indonesia) \\ ${ }^{2}$ English Education Deparment, Singaperbangsa University of Karawang, Indonesia)
}

* Corresponding Author. E-mail: ${ }^{1}$ lizaamelia02@gmail.com

\begin{tabular}{|l|l|l|}
\hline Receive: 13/05/2021 & Accepted: 23/08/2021 & Published: 01/10/2021 \\
\hline
\end{tabular}

\begin{abstract}
Instructional design is the art of creating and developing trainning experiences that make learning more efficient, effective and enjoyable for students (Merrill, 2012). This study aimed: (1). To find out how do teachers design online instruction during the Covid-19 pandemic; (2). To find out how are teachers perception in conducting online instructional design during the covid-19 pandemic. The participant of this study were an English teacher of senior high school in Karawang. This study used a qualitative narrative design. The instrument used for collecting the data is interview guideline that explained in the form of narrative inquiry. The result showed that by analyzing and understanding students' characteristic, the teacher could create online instructional design that suitable with the students' desire in learning. Meanwhile, related to teacher's perception, in conducting online instructional design in this pandemic. It made the teacher is difficult to carry out the learning materials effectively and achieve the maximum of learning process. In addition, the teacher had to adapt with a new system and it required her to be more creative and innovative in order the student had a motivation in learning during this pandemic. To all of this fact, it can be said that conducting online instructional design made teacher experiencing difficulties while preparing and applying the instruction.
\end{abstract}

Keywords: Online Learning, Instructional Design

\begin{abstract}
Abstrak
Desain instruksional adalah seni menciptakan dan mengembangkan pengalaman pelatihan yang membuat pelajaran lebih efisien, efektif dan menyenangkan bagi siswa (Merrill, 2012). Penelitian ini bertujuan: (1). Untuk mengetahui bagaimana guru merancang pembelajaran online selama Covid-19; (2). Untuk mengetahui bagaimana persepsi guru dalam melakukan desain pembelajaran online dimasa pandemi Covid-19. Partisipan dari penelitian ini adalah seorang guru Bahasa Inggris dari SMA Negeri di Karawang. Penelitian ini menggunakan desain naratif kualitatif. Instrumen yang digunakan untuk mengumpulkan data adalah wawancara yang dijelaskan dalam bentuk inkuiri naratif. Hasil penelitian menunjukan bahwa dengan menganalisis dan memahami karakteristik siswa, guru dapat membuat desain pembelajaran online yang sesuai dengan keinginan siswa dalam belajar. Sedangkan terkait dengan persepsi
\end{abstract}


guru dalam melakukan desain pembelajaran online di masa pandemi ini. Hal tersebut membuat guru sulit untuk melaksanakan dan menyampaikan materi secara efektif dan mencapai proses pembelajaran yang maksimal. Selain itu, guru harus beradaptasi dengan sistem baru dan dituntut untuk lebih kreatif dan inovatif agar siswa memiliki motivasi dalam belajar selama pandemi ini. Dari semua fakta ini, dapat dikatakan bahwa melaksanakan desain pembelajaran online membuat guru mengalami kesulitan saat mempersiapkan dan menerapkan desain instruksinya.

\section{Kata Kunci: Pembelajaran Online, Desain Instruksional}

\section{Introduction}

The world was schoked by a devastating illness in the beginning of 2019 known as Coranavirus Disease 2019. Many people in Wuhan and other countries, notably Indonesian were infected with this virus which resulted in fatalities in certain cases (Siagian, 2020). The Covid-19 also makes the all the teachers (K-12 teacher) are difficult in many countries and have to adapt online instruction as new system (Wang, 2021). The spread of the coronavirus are all around the world, including Indonesia. It affect all human activities in any aspect, especially in teaching and learning process (Syah, 2020). The learning process is carried out by the teacher and students through online learning. According to Richard and Hayya (2009) as cited in (Arkorful \& Abaidoo, 2015), in this pandemic, technology have become one of the most essential technology for teaching and learning process. An accurate instructional design should be founded on an appropriate learning theoritical approach. According to Branch \& Kopcha (2014, as quoted in (González \& Quiroz, 2019) say "instructional design is intended to be an iterative process of planning outcomes, selecting effective strategies for teaching and learning, choosing relevant technologies, identifying educational media and measuring performance".

(Karthik et al., 2019) who conducted the study about "Identification of Instructional Design Strategies for an Effective E-learning Experience". The result showed that the teachers' method is based on the variety of several aspects, including learners; knowledge and experience, the subject matter, and the learning environment. A defined purpose and goal are required for every teaching method. Using media components such as screencasts, movies, avatar, social support and simulation to enhance the corporate E-learning experience can be beneficial. Storytelling, gamification, and problem-based learning can help students to have more successful in Elearning experience. Furthermore, (Sutarto et al., 2020) in their study of "Teacher strategies in online learning to increase students' interest in learning during COVID-19 pandemic" said that the teachers' techniques for increasing students' interest in learning included providing the students with an understanding of how important the learning is, making the learning material concise, clear, and entertaining by using simple and an interesting media and in conducting reguler and continuous evaluations. Online learning may provide the students with something enjoyable.

Based on the study above, this current study want to find out the issue that relate to teachers' perception in designing and conducting online instruction. However, teachers faced some problems in teaching during online learning. The teacher should adapt with new system from offline class to online class for teaching and learning process. From that sudden transformation is forced teachers to get used to a new system. Therefore, before implementing a virtual learning classroom successfully, the anxious feeling must be solved. In addition, teachers required being creative and innovative in choosing a good design for teaching so the students are able to adapt with this new environment and enjoy during learning 
process, as stated by Partlow \& Gibbs (2003, as cited in (Dhawan, 2020).

Due to the situation, the objective of this present study is to find out and describe the applied of EFL Teachers' Instructional Design in Conducting Online Learning during Covid-19 Pandemic which directly experienced by the teachers in senior high school.

\section{Online Learning}

According to (Ramanathan et al., 2020), in the last of 2019, a new virus known as coronavirus or Covid-19 was discovered in a seafood market in Wuhan. This epidemic has forced a physical closure of companies, sporting events, and most notably, the education system that forcing all of the institution to switch to online platform. Online learning, according to Fry (2001 as cited in (Adedoyin \& Soykan, 2020), is the use of internet and other essential technologies to build and develop learning techniques or materials, delivering teaching, and manage a learning progra. Hrastinski (2008, as cited in (Adedoyin \& Soykan, 2020) revealed that there are two models of online learning such as asynchronous and synchronous online learning. However, in conducting online learning to be more effective and efficient, the teacher and institution must have a deeply awareness of the benefits and the weaknesses. That statement also states by (Singh \& Thurman, 2019) that asynchronous or synchronous learning experience is able to make the teaching process more studentscentered, inventive, and adaptable. Even the students may learn and communiate with the teacher and other students from any location (indipendent).

The shift from traditional face-to-face learning to online classes really makes a huge effect for teachers themselves. Indeed, educational institution would not be able to convert all of the curriculums into an online resource in one day. The three of the most difficult factors for online teaching are distance, scale, and individualized teaching and learning. When there is a compelling need to switch to an online learning style, learning media or applications may be quite beneficial in assisting the teaching learning process; they are Google Classroom, Google Meeting, Zoom, Whats App, etc. These applications can successfully be used as an alternative for faceto-face classes or online learning (Basilaia, 2020). Thus, from many application above, teachers must be able to operate well and make a good instructional design that make students enjoy in the online class.

\section{Instructional Design}

Instructional design techniques are the science of developing an organized instructions and requirements in order to design instructional material that will instruct the students (Martin, 2011 as cited in (Karthik et al., 2019). Instructional design according to (Merrill, 2012), is the art of creating and developing trainning experiences that make learning more efficient, effective and enjoyable for students.

In addition, for teachers, designing an instruction is very meaningful to determine a patterns or sequences consciously and systematically to make the learning process run effectively. From this perspective, when designing instruction, the teachers as an instruction designer have to choose an effective strategy based on the type of learning outcome and evaluate the expected learning outcomes (or objectives) to determine the effectiveness of the instruction. It indicates, that when delivering instruction, teacher should inform students about the aims and objectives of learning, assess learning requirements, give instructional stimuli, provide learning guidance, elicit performance, provide feeback, and measure learning outcomes, according to Gangne (1984, as cited in (Karthik et al., 2019). This common process that used is called the teacher-centered objectivist approach to instructional design and practice.

Thus, learning objectives, classroom prcedure and method, learners' role, teachers' role, role of instructional material, role of media are all components of instructional design. All of them are designed to provide students with a strong command of the English 
language, it is also allowing them to participate in a variety of academic activities.

\section{Method}

This research used narrative inquiry as a research design that related to the study. Narrative inquiry is a method of comprehending, enquiring, and gathering the information for the purpose of the research via storytelling of people's experience. "collaboration between researcher and participants, over time, in a place or series of places, and in social interaction with milieus", according to Clandinin \& Connelly (2000, as cited in (Jha, 2018). This study will investigate an English teacher in Senior High School in Karawang. In using narrative inquiry the researcher conducted the interview especially semi-structured interview as an instrument for collecting the data. The researcher provided several questions or interview guideline to be asked to the participants based on the focus of the study. For analyzing the data, the researcher used thematic analysis from (Braun $\&$ Clarke, 2006). It was done by the researcher to find out and gain more information about how teacher design the instruction and their perception in designing and conducting online learning.

\section{Findings and Discussion}

This chapter presented the findings of two subsections that related to the purpose of the study. The two subsections were divided into several points based on difference category. In the subsection of teachers design online instruction, the research findings presented three parts including teacher's belief, analyzing students characteristic and learning media. The second subsection about teacher's perception, the finding presented two parts including difficulties and diffirences. The following is a detailed explanation of the findings.

\section{Analyzing Students Characteristic in Designing Online Instruction}

In teaching and learning process, teacher will always redesign the instruction while delivering the materilas. It is because the teacher often face different characteristic of the students. It can be seen from the interview transcript result.

Researcher : How do you design the online instruction in this pandemic era?

Participant : In this online learning, I design the learning instruction that that is suited to the characteristics of students. So the students that I teach can be happy and comfortable. If I have understood it, the students can understand the material that I convey. Mainly, the design will also have different applications according to the characteristics of the students and take considerable time because experience alone is insufficient. Every student we face from year to year and the classes we teach from year to year are different.

From the interview trancript illustrated that in designing the online instruction, teacher was deeply aware about the comfort and the happiness of the students in learning. Teacher must be willing to follow students' desire by what method they wanted to learn. It was because the students' caharacteristic is one of the important factors that had to be understood by teacher and teacher could apply the design instruction that suitable for them. In addition, teacher should be aware about the effectiveness in learning method that made the students are interested. It can be proved from the interview transcript below.

Researcher : How do you develop your online instruction to keep the teaching process interesting?

Participant : The design that I develop depends on the situation and condition of what I face in the learning process in class. Usually at the end of the activity, I make the students practice from the previous matter. They will show uninterested feeling related to the activity. So, I have to be able to make the students are brave and willing to participate. Therefore, 
I make an interesting offer to them without being forced. After that the students will become curious and want to try. So, the way which I develop my instructional design is flexible according to the situation and condition.

Based on the interview transcription, developing online instruction is needed for teacher to help the learning process became more interesting and effective. It had similar statement to (Merrill, 2012) that instructional design is the art of creating and developing trainning experiences that make learning more efficient, effective and enjoyable for students. It also help the students dared to speak up in the class.

\section{Difficulties in Conducting Online Instruction}

During this pandemic, teacher faced several problems to adapt in a new system. It forced her to do the activities in a new normal condition. That statement can be proven by interview trancript below.

Researcher : What is your perception in conducting online instruction during the pandemic?

Participant : In conducting this online instruction, I faced several problems such as difficult to deliver learning materials due to the lack of learning time. In addition, it is difficult to manage students so that they are on time in joinning virtual classes.

The interview trancript above illustrated that conducting online instructional design in this pandemic made the teacher is difficult to carry out the learning materials effectively and achieve the maximum of learning process. Aside from that, the teacher and the students were being forced to have many learning applications. In designing online instruction, teacher need to choose what media that suit the best for the student.

Researcher: What media or platform do you use to support in conducting online instruction?
Participant : In carrying out learning using media, I had a little difficulty in choosing suitable media that all students could access it. In fact, not all the student have the same facilities. So usually I will offer to the students, what kind of media or application are you comfortable learning to use. So, in the end I will return to the situational and condition flexibly in using media as a tool to support my learning design.

From the interview transcript, it was illustrated that media as a learning tool is able to support the teacher to conduct the learning process. As stated by (Basilaia, 2020) that When there is a compelling need to switch to an online learning style, learning media or applications may be quite beneficial in assisting the teaching learning process. Beside, in choosing the media or the application that suitable for the student, the teacher gave the students choice to choose the comfortable media or the application that they wanted to use.

\section{Differences in Conducting between Online and Offline Instruction}

By changging the system of education in this pandemic, teacher felt several significant differences in carrying out the learning process. The result can be proven in interview transcript below.

Researcher : What significant differences do you feel in conducting between online and offline instrction?

Participant : In offline learning, I can guide and monitor students' behavior so that they have a good attitude. Besides that, in terms of learning material, I find it easier to deliver the material because I have much time. So that the material is also presented to the maximum. Meanwhile, while carrying out online learning at this time, I feel that the attitudes that exist in students are dicreased. In addition, in delivering material 
content, I must be required to be more creative and innovative to produce effective learning.

The interview transcript above, related to the teacher's perception in conducting online instruction. The teacher tended to implement the instruction as like in the offline than online learning. Teacher felt that in online learning, she found out several disadvantages toward her design instruction. Morevover, the teacher also was required to be more creative and innovatif in order the student had a motivation in learning during this pandemic. It also stated by Partlow \& Gibbs (2003 quoted in (Dhawan, 2020), teachers required being creative and innovative in choosing a good design for teaching so the students are able to adapt with this new environment and enjoy during learning process.

\section{Conlusion}

This current study concluded the result based on the findings and discussion which related to EFL Teacher Design in Conducting Online Instruction during the Cocid-19 Pandemic and EFL Teacher's perception. In the first subsection, analyzing students' characteristic became the important factors before the teacher designed her online instruction. the teacher needed to undestand students' characteristic before conducting the design instruction. It is because students' characteristic became one of the factors that had to be understood by teacher and teacher could apply the design instruction that suitable for them to achieve maximum learning in the class. Meanwhile in the second subsection, there were also two aspect related to teacher's perception. Those are difficulties and differences in conducting online instruction. In conducting online instructional design in this pandemic, it made the teacher is difficult to carry out the learning materials effectively and achieve the maximum of learning process. In addition, the teacher had to adapt with a new system and it required her to be more creative and innovative in order the student had a motivation in learning during this pandemic. It was because in conducting the instructional design for online and offline learning are different. To conlude the result, it can be said that conducting online instructional design in this pandemic, it is not as simply as thought. It makes teacher experiencing difficulties while preparing and applying the design instruction in the learning process.

\section{References}

Adedoyin, O. B., \& Soykan, E. (2020). Covid-19 pandemic and online learning: the challenges and opportunities. Interactive Learning Environments, $0(0), 1-13$. https://doi.org/10.1080/10494820.2020 .1813180

Arkorful, V., \& Abaidoo, N. (2015). The role of e-learning, advantages and disadvantages of its adoption in higher education. International Journal of Instructional Technology and Distance Learning, 12(1), 29-42.

Basilaia, G. (2020). Replacing the Classic Learning Form at Universities as an Immediate Response to the COVID-19 Virus Infection in Georgia. International Journal for Research in Applied Science and Engineering Technology, 8(3), 101108.

https://doi.org/10.22214/ijraset.2020.3 021

Braun, V., \& Clarke, V. (2006). Qualitative Research in Psychology Using thematic analysis in psychology Using thematic analysis in psychology. Qualitative Research in Psychology, 3(2), 77-101. http://www.tandfonline.com/action/jou rnallnformation?journalCode=uqrp $20 \%$ 5Cnhttp://www.tandfonline.com/action /journallnformation?journalCode=uqrp2 0

Dhawan, S. (2020). Online Learning: A Panacea in the Time of COVID-19 Crisis. Journal of Educational Technology Systems, 49(1), 5-22. https://doi.org/10.1177/004723952093 4018

González, L. F. M., \& Quiroz, V. G. (2019). Instructional Design in Online Education: 
Jurnal Edumaspul, 5 (2), Year 2021 - 802

(Liza Amelia Syafitri, Yousef Bani Ahmad, Abdul Kodir Al-Baekani)

a Systemic Approach. European Journal of Education, 2(3), 64. https://doi.org/10.26417/ejed.v2i3.p6473

Jha, S. K. (2018). Narrative Texts in Narrative Inquiry: Interpretive Voices to Better Understand Experiences in Given Space and Time. Open Journal of Leadership, 07(04), 237-249. https://doi.org/10.4236/ojl.2018.74014

Karthik, B. S. S., Chandrasekhar, B. B., David, R., \& Kranthi Kumar, A. (2019). Identification of instructional design strategies for an effective E-learning experience. Qualitative Report, 24(7), 1537-1555.

https://doi.org/10.46743/2160-

3715/2019.3870

Merrill, M. D. (2012). First Principles of Instruction. John Wiley \& Sons. https://www.wiley.com/enus/First+Principles+of+Instruction-p9780470900406

Ramanathan, K., Antognini, D., Combes, A., Paden, M., Zakhary, B., Ogino, M., Maclaren, G., \& Brodie, D. (2020). Clinical features of patients infected with 2019 novel coronavirus in Wuhan, China. The Lancet, 395(January), 497-506.

Siagian, T. H. (2020). Corona Dengan Discourse Network Analysis. Jurnal Kebijakan Kesehatan Indonesia, 09(02), 98-106.

Singh, V., \& Thurman, A. (2019). How Many Ways Can We Define Online Learning? A Systematic Literature Review of
Definitions of Online Learning (19882018). American Journal of Distance Education, 33(4), 289-306. https://doi.org/10.1080/08923647.2019 .1663082

Sutarto, S., Sari, D. P., \& Fathurrochman, I. (2020). Teacher strategies in online learning to increase students' interest in learning during COVID-19 pandemic. Jurnal Konseling Dan Pendidikan, 8(3), 129. https://doi.org/10.29210/147800

Syah, R. H. (2020). Dampak Covid-19 pada Pendidikan di Indonesia: Sekolah, Keterampilan, dan Proses Pembelajaran. SALAM: Jurnal Sosial Dan Budaya Syar-I, 7(5).

https://doi.org/10.15408/sjsbs.v7i5.153 14

Wang, C. X. (2021). CAFE: An Instructional Design Model to Assist K-12 Teachers to Teach Remotely during and beyond the Covid-19 Pandemic. TechTrends, 65(1), 8-16. https://doi.org/10.1007/s11528020-00555-8

\section{About the Author(s):}

${ }^{1}$ Liza Amelia Syafitri is a students of English Education Department from University of Singaperbangsa Karawang

${ }^{2}$ Yousef Bani Ahmad is an author's first advisor in Faculty of Teachers Training and

Education of Singaperbangsa University of Karawang

${ }^{3}$ Abdul Kodir Al-Baekani is an author's second advisor in Faculty of Teachers Training and Education of Singaperbangsa University of Karawang 